\title{
Concurrent uveoretinitis and pineocytoma in a child suggests a causal relationship
}

Niels Illum, Horst W Korf, Kim Julian, Tommy Rasmussen, Margrethe Herning, Søren Krabbe

\section{Abstract}

Uveoretinitis was observed in a 9-year-old girl 6 months prior to the clinical appearance of a pineal tumour. Surgical removal was not successful but biopsy revealed a parenchymal neoplasm with differentiated pinealocytes and absent mitotic activity. Some of the tumour cells contained S-antigen, rhodopsin, and serotonin. Systemic glucocorticoid therapy followed by radiation therapy caused considerable reduction in size of the tumour and a complete normalisation of all eye symptoms. This report demonstrates for the first time that a pineocytoma can occur together with uveoretinitis in humans. The latter resembles the experimentally induced autoimmune uveoretinitis described in animals. It is speculated that the retinitis might reflect an autoimmune response to $\mathrm{S}$-antigen present in some tumour cells of the pineocytoma.

(Brf Ophthalmol 1992; 76: 574-576)

The retina and the pineal organ of all vertebrates, including humans, share several molecules and proteins. ${ }^{12}$ One of these is the highly antigenic Santigen located in the retinal photoreceptors and pinealocytes. ${ }^{\prime 2}$ When administered in small amounts to susceptible animals the S-antigen induces an inflammatory response in the uveal tract, retina, and pineal gland. ${ }^{2}$ This is considered as a paradigm to clarify the nature and mechanism of inflammatory eye disease in humans. ${ }^{3}$ However, it has not yet been established whether immunological eye diseases in humans coincide with pathological changes in the pineal organ or vice versa. We report a patient suffering from a

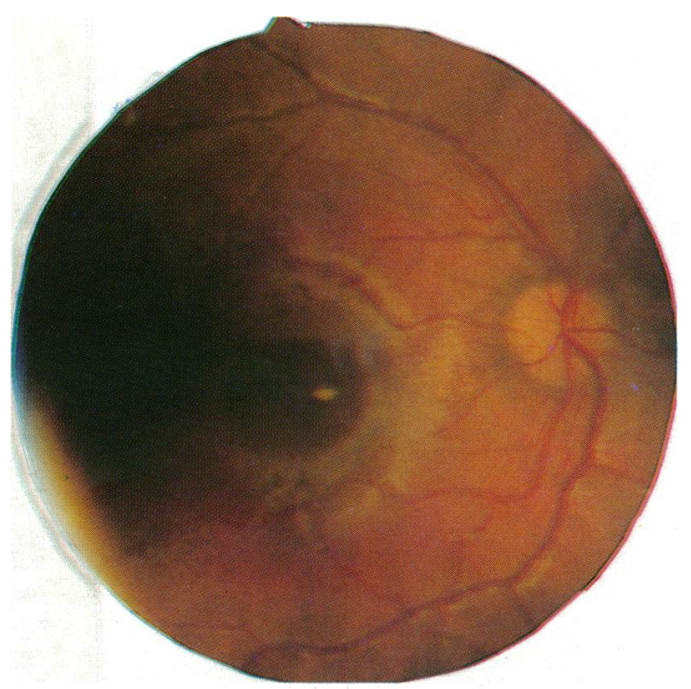

\section{Materials and methods}

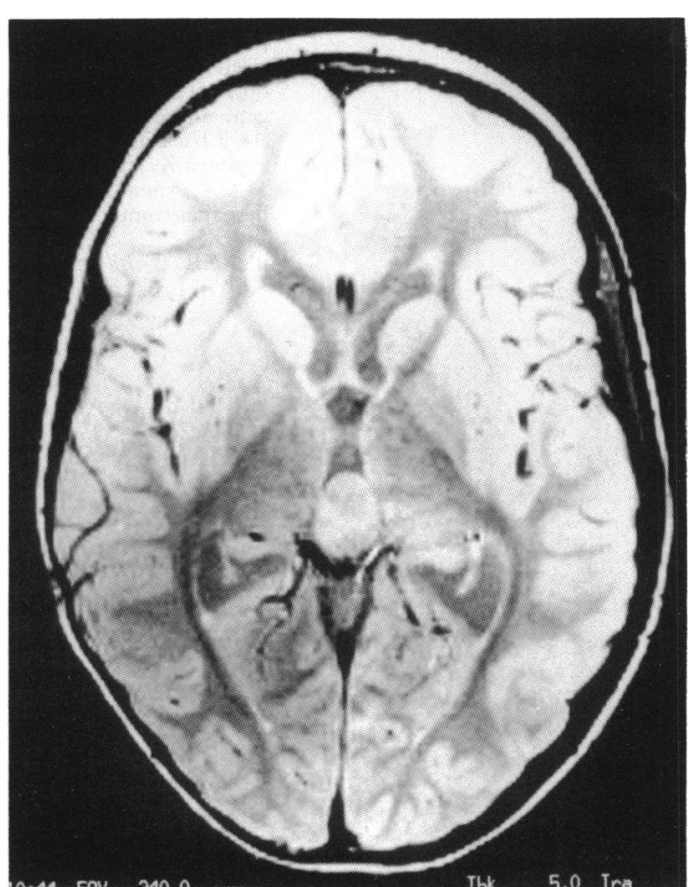

Figure 2 Magnetic resonance imaging studies showing the pineocytoma before radiation therapy.

pineocytoma associated with uveoretinitis and suggest a causal relationship between both symptoms.

\section{CASE REPORT}

A 9-year-old otherwise healthy Caucasian girl presented with bilateral iritis followed 3 months later by a retinal oedema in the central fovea of the right eye. Cycloplegics and topical corticosteroids cleared the inflammation which, however recurred upon subsequent attempts to reduce the corticosteroid doses. Eight months after referral a sudden reduction of vision was experienced. The optic nerve was pale, swollen, and protruded 2 dioptres. Iritis reappeared together with retinitis, presenting as intraretinal macular oedema (Fig 1) and intraretinal oedema in the periphery of the retina of both eyes. Retinal vasculitis or retinal pigment epithelial detachment was not evident by repeated ophthalmic examinations in this young girl. Campimetric examination disclosed bitemporal visual field defects. Magnetic resonance imaging showed hydrocephalus and a pineal tumour obstructing the aqueduct (Fig 2). Systemic glucocorticoid therapy and a shunt operation completely reversed the symptoms. Radiation therapy was administered and 1.5 years later the 
gland had returned to a normal size. Ophthalmic examinations remained normal even after the glucocorticoid therapy had been stopped during radiation. Tissue typing showed that the patient carried antigens HLA-A28 DR4.

\section{HISTOLOGY}

The pineocytoma consisted of small, dark, and round nuclei arranged in groups and with occasional rosette formations. Mitoses could not be detected (Fig 3).

\section{IMMUNOCYTOCHEMISTRY}

Paraffin sections were used for the demonstration of S-antigen, rhodopsin, and serotonin. The Santigen antibody (raised in rabbits) was a generous gift from Dr I Gery, National Eye Institute, Bethesda, MD, USA. The rhodopsin antibody (raised in rabbits) was kindly provided by Dr W J de Grip, Department of Biochemistry, University of Nijmegen, Nijmegen, The characterised. ${ }^{4-8}$ The serotonin antibody was purchased from IBL, Hamburg, Germany. All antibodies were diluted with phosphate buffered saline (PBS) containing $1 \%$ bovine serum albumin and $0.3 \%$ Triton X-100 (Sigma, St Louis, MO, USA) to a final concentration of $1: 1000$. Binding was visualised by the peroxidase-antiperoxidase method. ${ }^{49}$

IMMUNOLOGICAL ANALYSIS OF CSF SAMPLES

CSF samples were obtained 19 days after the shunt operation and processed for SDSpolyacrylamide gel electrophoresis. ${ }^{10}$ The proteins were then electroblotted onto nitrocellulose, incubated with the S-antigen antibody (diluted 1:4000) and binding was visualised by the peroxidase-antiperoxidase method.

\section{Results}

Figure 3 Pineocytoma composed of cells with small, dark and round nuclei.

Occasional rosette formation is noted. Mitoses could not be detected. $\times 85$.

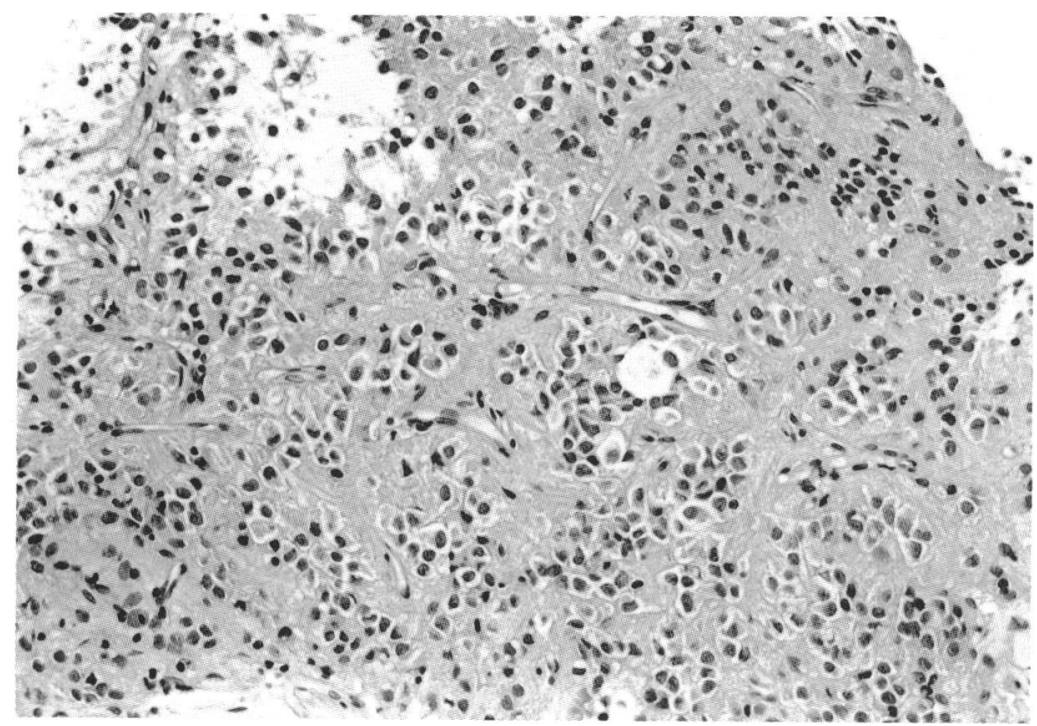

\section{HISTOLOGY}

Immunohistological examination for the Netherlands. Both antibodies have been well

presence of T cell markers LCA, 4KB5, L-26, $\mathrm{CD} 3$ and $\mathrm{UCHL}-1$ was negative.

\section{IMMUNOHISTOCHEMISTRY}

S-antigen, rhodopsin, and serotonin immunoreactions were observed in certain tumour cells scattered among immunonegative elements which formed the major portion of the tumour. S-antigen appeared evenly distributed in the cytoplasm and was absent from the cell nuclei (Fig 4a). Rhodopsin immunoreaction was mainly demonstrated in the periphery of the cells (Fig 4b). The rhodopsin immunoreactive cells were less frequent than those containing immunoreactive S-antigen. The serotonin immunoreaction was evenly distributed in the cytoplasm or concentrated in the periphery of certain cells (Fig 4c) whose number and distribution closely resembled those of the S-antigen immunoreactive cells.
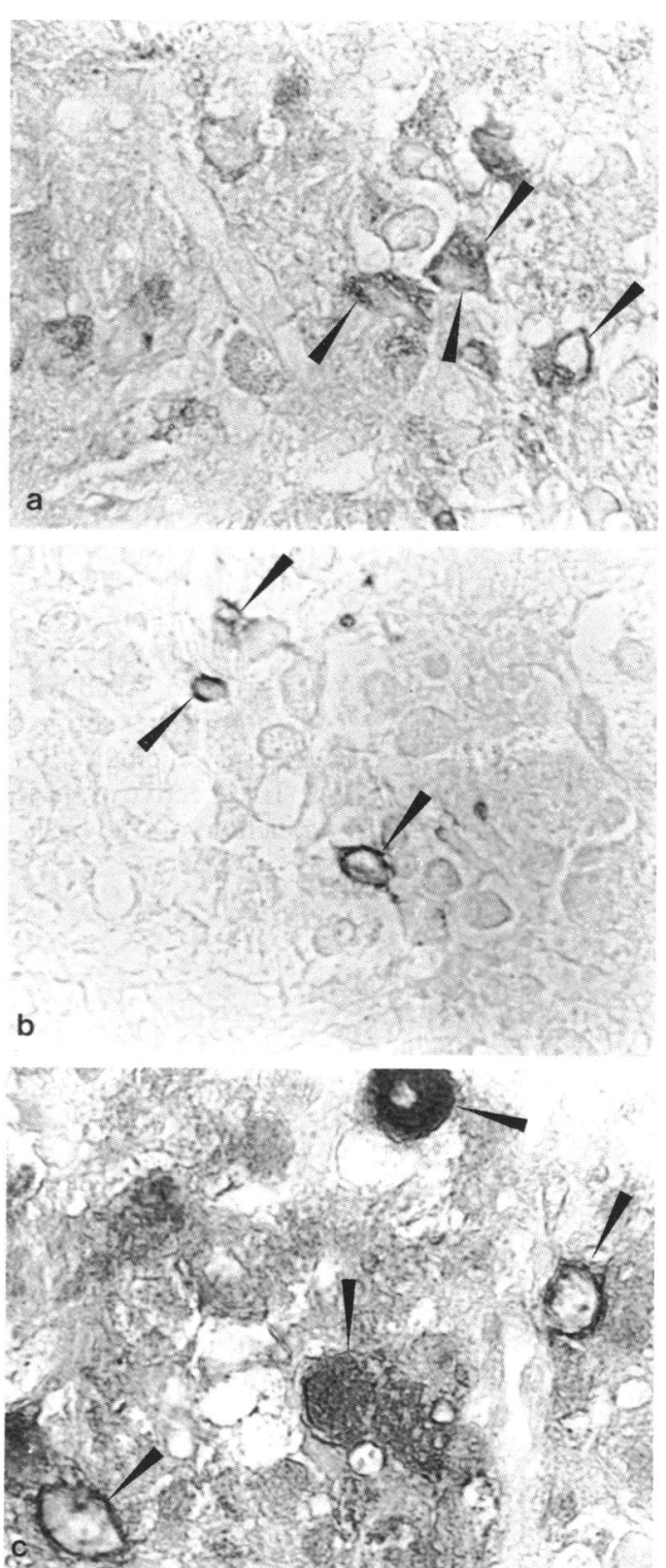

Figure 4 Immunocytochemical demonstration of $S$-antigen $(a)$, rhodopsin $(b)$, and serotonin $(c)$ in paraffin sections of the tumour biopsy. Arrowheads indicate immunoreactive cells, $a, b \times 350, c \times 480$ 
IMMUNOCHEMICAL ANAL YSES OF CSF SAMPLES Immunochemical (western blot) analysis failed to demonstrate a protein band reacting with Santigen antibody.

\section{Discussion}

We report a 9-year-old girl suffering from uveoretinitis and a tumour of the pineal region classified as a pineocytoma by histological features and demonstration of S-antigen, rhodopsin, and serotonin immunoreactions in some tumour cells. ${ }^{51011}$ The simultaneous occurrence of uveoretinitis and a pineal tumour, and the disappearance of all ophthalmic manifestations upon tumour therapy suggest that both symptoms may be related and resemble those found in experimental autoimmune uveoretinitis with associated pinealitis. The autoimmune reaction, which has an anterior as well as a posterior component, is shortlived and disappears when the provoking factor is eliminated. ${ }^{2}$

Though we cannot explain exact methods of immune stimulation - the apparent absence of $T$ cells from the tumour and $\mathrm{S}$-antigen from the $\mathrm{CSF}^{10}$ - the presence of $\mathrm{S}$-antigen in tumour cells might still be an important pathogenetic factor. Moreover considering the presence of S-antigen in certain cerebellar medulloblastomas, ${ }^{7}$ it is surprising that $\mathrm{S}$-antigen containing tumours have not presented with uveitis in the past. An association with certain antigens determined by the major histocompatibility complex could play a role. The Vogt-Koyanagi-Harada syndrome is associated with HLA-DR53 in Japanese but with HLA-D4 in American patients. ${ }^{12}$ Our patient had DR4. Other immune mechanisms involved could be the way uveitogenic epitopes of the Santigen are presented to the immune system, ${ }^{2}$ selective involvement of pathogenic $T$ cells with a restricted $\mathrm{T}$ cell receptor $\mathrm{V}$ gene usage, ${ }^{2}$ or an inappropriate suppression of an autoimmune response elicited. ${ }^{13}$

Irrespective of these unresolved problems, we conclude on the basis of the clinical experience obtained from the care of this child that a tumour of the pineal gland should be included in the differential diagnosis of uveitis in childhood. These tumours often have a more malignant course in children than in adults, ${ }^{14}$ and symptoms in the eye could precede the classic symptoms of an expanding and obstructing pineal process by several months.

This investigation was partially supported by a grant from the Deutsche Forschungsgemeinschaft to HWK (Ko 758/3-2).

1 Kalsow CM. Pineal and retinal relationships in the immunopathology of experimental autoimmune uveitis. In: Usui $M$ Ohno S, Aoki K, eds Ocular immunology today. New York: Elsevier, 1990; 139-42.

2 Merryman CF Donoso LA, Zhang X, Heber-Katz E Gregerson DS. Characterization of a new, potent, immunopathognic V 8 8 and VB 2-like genes. F Immunol 1991; 146: 75-80.

3 Nussenblatt RB, Mittal KK, Ryan S, Green K, Maumenee AE. Birdshot retinochoroidopathy associated with HLAAE. Birdshot retinochoroidopathy associated with HLAA29 antigen and immune responsiveness

4 Korf HW, Møller M, Gery I, Zigler JS, Klein DC. Immunocytochemical demonstration of retinal S-antigen in the pineal organ of four mammalian species. Cell Tissue Res 1985; 239: 81-5

5 Korf HW, Klein DC, Zigler JS, Gery I, Schachenmayr W. Santigen-like immunoreactivity in a human pineocytoma. Acta Neuropathol (Berl) 1986; 69: 165-7.

6 Korf HW. Zur Frage photoneuroendokriner Zellen und Systeme: Vergleichende Untersuchungen am Pinealkomplex. Thesis, University of Giessen, 1986

7 Korf HW, Czerwionka M, Reiner J, Schachenmayr W, Schalken JJ, de Grip W, et al. Immunocytochemical evidence of molecular photoreceptor markers in cerebellar medulloblastomas. Cancer 1987; 60: 1763-6.

8 Korf HW, Foster RG, Ekström P, Schalken JJ. Opsin-like immunoreaction in the retinae and pineal organs of four mammalian species. Cell Tissue Res 1985; 242: 645-8.

9 Sternberger LA, Hardy PH, Cuculis JJ, Meyer HG. The unlabelled antibody enzyme method of immunohistochemistry. Preparation and properties of soluble antigenchemistry. Preparation and properties of soluble antigenantibody complex (horseradish peroxidase-anthorseradish peroxidase) and its use in identification of spirochetes. Histochem Cytochem 1970; 18: 315-33.

10 Korf HW, Bruce JA, Vistica B, Rollag M, Stein BM, Klein DC. Immunoreactive $S$-antigen in cerebrospinal fluid: a marker of pineal parenchymal tumors? F Neurosurg 1989; 70: 682-7.

11 Perentes E, Rubinstein LJ, Herman MM, Donoso LA. Santigen immunoreactivity in human pineal glands and pineal parenchymal tumors. A monoclonal antibody study. Acto Neuropathol (Berl) 1986; 71: 224-7.

12 Bienfang DC, Kelly LD, Nicholson DH, Nussenblatt RB. Ophthalmology. N Engl f Med 1990; 323: 956-67.

13 Cohen IR, Young DB. Autoimmunity, microbial immunity and the immunological homunculus. Immunol Today 1990; 12: 105-10.

14 Disclafani A, Hudgins RJ, Edwards MSB, Wara W, Wilson CB, Levin VA. Pineocytomas. Cancer 1989; 63: 302-4. 